\title{
TIPOLOGI KLASTER HILIRISASI KARET DI PROVINSI JAMBI
} TYPOLOGY OF RUBBER DOWNSTREAM CLUSTERS IN JAMBI PROVINCE

\author{
Novita Erlinda \\ Badan Penelitian dan Pengembangan Daerah Provinsi Jambi \\ JI. R.M. Nur Atmadibrata No. 01 A Telanaipura Jambi, \\ ne.novitaerlinda@gmail.com
}

\begin{abstract}
Rubber has been a prime commodity for rural farmers in Jambi. It has been the main foundation of rural livelihood for rural people as it creates multiplier effect to rural economy. Nevertheless, income of rubber farmers in general is still lower compare with other occupations or even other farming activities. Fluctuation of rubber prices as well low capacity of bargaining position of the farmers in the market have created viciious circle of low income in rubber farmers. These situations have driven the governmen to implement the downstreaming of the processed rubber products. Hilirisasi is one policy solutions that is expected to improve the welfare of rubber farmers. This paper aims to identify the typology of rubber downstream clusters in Jambi Province, and to map the relationships among actors in the implementation of rubber downstream policies. The research focuses on six districts rubber plantation areas in Jambi Province, namely Merangin, Sarolangun, Bungo, Tebo, Batanghari and Muaro Jambi. The data used in the form of primary and secondary data. The analysis was carried out by means of prospective analysis using MACTOR tool. The results of the analysis yielded three typologies of downstreaming clusters, namely: 1. HVLV cluster based on hight volume and low volume; 2. EMLM cluster based on export and local markets, and 3. HMLM cluster based on high and low mulplier effects. The relationship among actors in the implementation of rubber downstream policy were mapped based regulation or institutional and incentive scehems. It shows that rubber farmers always on bargaining position very low among other actors. Lessons learned and policy recommendation to improve the bargaining position of the farmer were highlighted.
\end{abstract}

Keywords: Downstreaming Rubber products, Prospective Analysis, MACTOR

\begin{abstract}
Abstrak
Karet telah menjadi komoditas utama bagi petani pedesaan di Jambi. Ini telah menjadi pondasi utama penghidupan pedesaan bagi masyarakat pedesaan karena menciptakan efek berganda terhadap ekonomi pedesaan. Namun demikian, pendapatan petani karet secara umum masih lebih rendah dibandingkan dengan pekerjaan lain atau bahkan kegiatan pertanian lainnya. Fluktuasi harga karet serta rendahnya kapasitas posisi tawar petani di pasar telah menciptakan lingkaran setan berpenghasilan rendah di petani karet. Situasi ini telah mendorong pemerintah untuk menerapkan hilirisasi produk karet olahan. Hilirisasi adalah salah satu solusi kebijakan yang diharapkan dapat meningkatkan kesejahteraan petani karet. Tulisan ini bertujuan untuk mengidentifikasi tipologi klaster hilir karet di Provinsi Jambi, dan untuk memetakan hubungan antar aktor dalam implementasi kebijakan hilir karet. Penelitian ini fokus pada enam kabupaten yang memiliki perkebunan karet rakyat di Provinsi Jambi, yaitu Merangin, Sarolangun, Bungo, Tebo, Batanghari dan Muaro Jambi. Data yang digunakan berupa data primer dan sekunder. Analisis dilakukan dengan cara analisis prospektif menggunakan alat MACTOR. Hasil analisis menghasilkan tiga tipologi cluster downstreaming, yaitu: 1. HVLV cluster berdasarkan volume tinggi dan volume rendah; 2. Kelompok EMLM berdasarkan pasar ekspor dan lokal, dan 3. Kelompok HMLM berdasarkan mulplier efek tinggi dan rendah. Hubungan antar aktor dalam implementasi kebijakan hilir karet dipetakan berdasarkan peraturan atau kelembagaan dan sistim insentif. Hal ini menunjukkan bahwa petani karet selalu berada pada posisi tawar yang sangat rendah di antara para pelaku lainnya. Pelajaran yang dipetik dan rekomendasi kebijakan untuk meningkatkan posisi tawar petani menjadi sorotan.
\end{abstract}

Kata kunci: Hilirisasi produk karet, Prospective Analysis, MACTOR

\section{PENDAHULUAN}

Indonesia sebagai produsen karet

alam terbesar kedua di dunia. Karet alam

di Indonesia $80 \%$ diproduksi oleh petani kecil dan hanya $20 \%$ diproduksi oleh

industri karet domestik (Karyudi, 2017).

Adapun provinsi di Indonesia sebagai 
penyumbang karet alam terbesar secara berurutan yakni Provinsi Sumatera Selatan, Sumatera Utara, Riau, Jambi, dan Kalimantan Barat (Statistik Perkebunan Indonesia, 2017). Fakta menarik terkait pemasaran karet alam Indonesia yaitu rendahnya konsumsi karet domestik, dengan kata lain bahwa Indonesia mengekspor $85 \%$ karet mentah (Indonesia Investment.com ).

Menurut data statistik perkebunan pada tahun 2017 areal perkebunan karet di Provinsi Jambi seluas $668.919 \mathrm{Ha}$ atau 42 persen dari total luas areal perkebunan yang ada. Secara rinci terdiri dari tanaman belum menghasilkan 198.296 Ha, tanaman menghasilkan $359.107 \mathrm{Ha}$ dan tanaman tua atau rusak seluas $111.516 \mathrm{Ha}$. Sedangkan menurut pengusahaannya, luas perkebuan karet Provinsi Jambi didominasi oleh perkebunan rakyat seluas $664.704 \mathrm{Ha}(99,4 \%)$ dengan produksi 328.563 Ton, dan Perkebunan Besar Swasta $4.215 \mathrm{Ha}$ dengan produksi 3.100 Ton. Dimana luas dan produksi tersebut setiap tahun mengalami peningkatan (Dinas Perkebunan Provinsi Jambi, 2017).

Lokasi pengembangn kawasan perkebunan berbasis karet di Provinsi Jambi telah ditetapkan secara nasional oleh Kementerian Pertanian RI yaitu Kabupaten Batanghari, Muaro Jambi, Tebo, Merangin dan Sarolangun (Keputusan Menteri Pertanian Republik Indonesia Nomor: 830/ Kpts/RC.040/12/2016). Hal ini juga didukung oleh Masterplan Pengembangan
Per-kebunan Berbasis Karet di Provinsi Jambi, dengan arah kebijakan yang terdiri dari: 1. Meningkatkan kemampuaan dan kete-rampilan pengelola perkebunan karet dan kapasitas kelembagaan perkebunan karet; 2.Meningkatkan investasi pembangunan perkebunan karet yang berwawasan lingkungan; 3.Mengembangkan sistem infor-masi dan pemanfaatan teknologi dan inovasi perkebunan karet yang handal; 4 . Meningkatkan mutu dan nilai tambah hasil perkebunan karet; 5. Mengembangkan kawasan perkebunan karet yang unggul dan berdaya saing.

Jumlah petani karet di Provinsi Jambi sebanyak 256.256 KK atau sekitar 39,4\% dari seluruh jumlah petani perkebunan (Dinas Perkebunan, 2017). Hal ini dapat diartikan bahwa 39,4\% petani di Provinsi Jambi masih menggantungkan hidupnya dengan komoditi karet. Pada sisi lain karet juga memberikan kontribusi yang cukup besar terhadap perputaran ekonomi daerah Jambi. Kontribusi sektor perkebunan yang didukung oleh nilai ekspor karet di Provinsi Jambi mencapai US \$ 432,052 juta pada tahun 2015 (Disperindag Provinsi Jambi, 2017). Fenomena ini tidak berbanding lurus dengan permasalahan yang terjadi dalam pengusahaan komoditi karet di lapangan, diantaranya: 1. Masih rendahnya produktivitas tanaman yakni rata-rata hanya 924 $\mathrm{Kg} / \mathrm{Ha} / \mathrm{Th}$; 2. Masih rendahnya mutu bahan olah karet yang dihasilkan; 3. Harga karet yang diterima petani sangat rendah. Ketiga permasalah pokok di atas saling 
berkaitan dan sangat mempengaruhi pendapatan yang diperoleh petani (Dinas Perkebunan, 2017).

Pemerintah Daerah Provinsi Jambi telah melakukan berbagai upaya untuk mengatasi permasalahan pengusahaan produk karet. Pada konteks peningkatan produktivitas tanaman, Pemerintah Pusat dan Pemerintah Daerah secara rutin mengalokasikan dana untuk kegiatan bantuan benih unggul dan sarana produksi lainnya. Kemudian untuk meningkatkan mutu bahan olah karet dilakukan pembinaan teknis dan bantuan peralatan sadap serta bangunan berupa Unit Pengolahan dan Pemasaran Bokar (UPPB). Kegiatan pemasaran pada UPPB diharapkan dapat mempersingkat mata rantai penjualan bokar petani, dengan harapan dapat mening-katkan nilai jual Bokar petani. Pemerintah Provinsi Jambi sejak tahun 2013 telah melaksanakan pelatihan hilirisasi industri karet dan pendampingan terhadap petani karet serta bantuan peralatan pengolahan karet alam di daerah sentra produksi karet seperti diantaranya di Kabupaten Bungo, Muaro Jambi, Kabupaten Sarolangun, dan Kabupaten Batanghari. Pada konteks pemasaran produksi, selama ini petani hanya menjual hasil kebunnya dalam bentuk bahan olah karet seperti slab yang sebagaian besar dijual melalui pedagang perantara atau pengumpul di desa, dan selanjutnya dijual ke pabrik crumb rubber. Kemudian pabrik crumb rubber mengolah Bokar (Bahan olahan produk karet) menjadi SIR 20 untuk selanjutnya di ekspor. Walaupun komoditi karet telah memberikan kontribusi terhadap perolehan devisa, namun petani karet belum merasakan nilai tambah dari penjualan Bokar, karena harga yang diterima tidak menguntungkan dan tidak ada standar yang transparasi dalam menentukan harga karet. Panjangnya mata rantai dalam pemasaran Bokar merupakan salah satu penyebab petani tidak menikmati nilai tambah dari hasil karetnya. Selain itu harga karet juga ditentukan oleh faktor eksternal seperti harga karet global yang dipengaruhi oleh harga minyak mentah dunia, protecsionism ekonomi, dan pelemahan ekonomi global (Balitbangda Provinsi Jambi, 2017).

Berbagai regulasi telah terbit untuk mendukung hilirisasi karet. Diantara regulasi terkait yaitu UU Nomor 3 Tahun 2014 tentang perindustrian atau merupakan regulasi awal dari kebijakan hilirisasi karet. Sejak itu Kementerian Perindustrian menyusun kebijakan yang mendorong tumbuhnya sektor industri yang meng-gerakkan perekonomian nasional. Selanjutnya diperkuat dengan penetapkan PP Nomor 4 Tahun 2015 tentang Rencana Induk Pembangunan Industri Nasional (RIPIN) 2015-2035. RIPIN mengarahkan untuk "menjadi negara industri tangguh yang bercirikan struktur industri nasional yang kuat, sehat dan berkeadilan; industri yang berdaya saing tinggi di tingkat global dan industri yang berbasis inovasi dan teknologi". Pentingnya komoditas karet dan 
industri hilirnya juga telah diatur dalam Peraturan Presiden Nomor 28 tahun 2008, Industri karet dan plastik merupakan bagian dari kelompok industri yang diprioritaskan dalam pengembangannya.

Selain itu Pemerintah melalui Kementerian Pertanian mengeluarkan kebijakan pengembangan agribisnis karet, baik di bidang on farm maupun off farm. Kebijakan operasional di tingkat on farm yang diperlukan bagi pengembangan agribisnis karet adalah : (a) Penggunaan klon unggul dengan produktivitas tinggi (3000 kg/ha/th); (b) Percepatan peremajaan karet tua seluas 1,2 juta ha sampai dengan tahun 2025; (c) Diversifikasi usahatani karet dengan tanaman pangan sebagai tanaman sela dan ternak; dan (d) Peningkatan efisiensi usahatani. Pemerintah juga telah menetapkan sasaran pengembangan produksi karet Indonesia sebesar 3-4 juta ton per tahun pada tahun 2025. Sasaran produksi tersebut hanya dapat dicapai apabila areal perkebunan karet rakyat yang saat ini yang produktivitasnya rendah berhasil diremajakan. Peremajaan karet tersebut menggunakan klon karet unggulan yang dilakukan secara berkesinambungan.

Pentingnya agribisnis dan agroindustri karet untuk peningkatan kesejahteraan petani telah pula sesuai dengan Visi Misi Jambi Tuntas 2021 yaitu meningkatkan daya saing daerah melalui optimalisasi pembangunan ekonomi kerakyatan ber-basis agribisnis dan agroindustri. Upaya yang perlu dilakukan pemerintah adalah dengan memberikan bantuan sarana produksi, seperti bibit unggul, pupuk, pestisida dan peralatan, sehingga mampu mengurangi beban petani sekaligus meningkatkan produktivitas karet alam. Namun penerapan kebijakan ini belum diiringi dengan pengawasan yang ketat, sehingga bantuan yang diberikan tidak digunakan, bahkan untuk komoditas lainnya seperti kelapa sawit. Selain itu, bantuan yang diberikan tersebut belum dapat dirasakan oleh petani secara merata.

Selanjutnya regulasi terkait dengan pemasaran Bahan Olahan Karet (bokar) juga telah diatur dan tertuang pada Peraturan Menteri Pertanian Nomor 38/Permentan/ OT.140/8/2008 tentang Pedoman Pengolahan dan Pemasaran serta Peraturan Menteri Perdagangan Nomor 53/MDAG/PER/10/2009 tentang Pengawasan Mutu Bahan Olah Komoditi Ekspor Standard Indonesian Rubber yang diperdagangkan. Pada tingkat hilir kebijakan operasional yang dikembangkan yakni (a) Peningkatan kualitas bokar berdasarkan SNI; (b) Peningkatan efisiensi pemasaran untuk meningkatkan marjin harga petani; (c) Penyediaan kredit usaha mikro, kecil dan menengah untuk peremajaan, pengolahan dan pemasaran bersama; (d) Pengem-bangan infrastruktur; (e) Peningkatan nilai tambah melalui pengembangan industri hilir; dan (f) Peningkatan pendapatan petani melalui perbaikan sistem pemasaran dan lain-lain.

Kelembagaan terkait dengan pengolahan bokar telah dipayungi oleh 
Peraturan Gubernur Provinsi Jambi No. 15 Tahun 2016 tentang Petunjuk pelaksanaan pengolahan, pemasaran dan pengawasan bokar yang diperdagangkan di Provinsi Jambi. Kemudian untuk mewujudkan keinginan dalam meningkatkan mutu Bokar yang sesuai dengan baku mutu, kegiatan pengolahan bokar dipusatkan pada UPPB sebagai unit kerja yang dibentuk oleh 2 sampai 3 kelompok petani pekebunan. UPPB berfungsi memberikan pelayanan teknis pengolahan maupun pengembangan usaha pemasaran bokar milik anggota kelompok, dimana UPPB telah dilengkapi dengan peralatan dan bahan yang diperlukan dalam proses pengolahan bokar serta didampingi oleh seorang tenaga teknis dan administrasi yang berasal dari salah satu anggota pekebun yang sudah terlatih. Sedangkan kelembagaan formal dengan seperangkat aturan formal yang masuk dalam sistem kelembagaan tataniaga karet rakyat dalam melaksanakan hilirisasi karet di Provinsi Jambi yaitu : Kelompok Tani, Gabungan Kelompok Tani, Asosiasi Petani, Koperasi/KUD, pool lelang, dan kemitraan.

Bertolak dari latar belakang dan berbagai kendala yang dihadapi petani baik dari sektor hulu dan hilir sangat diperlukan kehadiran pemerintah dalam mengeluarkan kebijakan yang diharapkan dapat mengatasi masalah dan memberikan solusi dari permasalahan yang dihadapi petani karet. Studi ini dilakukan untuk menemukan tipologi klaster hilirisasi karet di Provinsi Jambi dan memetakan kekuatan hubungan antar aktor dalam melaksanakan kebijakan hilirisasi karet di Provinsi Jambi. Penuh harapan dapat menjadi salah satu rekomendasi kebijakan yang menjadi jawaban diantara permasalahan pengem-bangan hilirisasi karet di Provinsi Jambi.

\section{METODE}

Penelitian ini dilakukan pada enam kabupaten penghasil karet yang terbesar di Provinsi Jambi menurut data statistik perkebunan tahun 2017, yaitu Kabupaten Merangin, Sarolangun, Tebo, Bungo, Batanghari dan Muaro Jambi. Data primer dan sekunder yang diperoleh diolah dengan pengan pendekatan metode Prospective analysis. Dimana Prospective analysis merupakan metode yang digunakan untuk mengkaji suatu kebijakan kedepan. Pada penelitian ini, Prospective analysis mengacu pada pemikiran Ahmed et al,. (2009), Godet (1989, 2006), dan Fauzi (2017), dengan menggunakan tool MACTOR. MACTOR atau Methode Acteurs, Objective, Repports de Force pada kasus ini digunakan untuk memetakan kekuatan hubungan antar aktor dan faktor dalam mengembangkan tipologi klaster hilirisasi karet di Provinsi Jambi.

Cara kerja MACTOR dilakukan melalui pengisian matrik posisi atau matrik 1 MAO (Matrix Actor-Objective) dan matrik 2MAO. Matrik selanjutnya yang akan dilengkapi yaitu matrik MID (Matrix Influence Direct) yang menggambarkan 
variabel pengaruh (influence). Setelah mengisi matrik MID dan $1 \mathrm{MAO}$, kemudian MACTOR akan menghitung matrik 2MAO melalui program komputer. Sistem kerja MACTOR sebagaimana mengacu pada pemikiran Godet (1989), sebagaimana diuraikan dengan formula berikut :

$$
M I D I_{A \rightarrow B}=M I D I_{A \rightarrow B}+\sum_{C}\left[\min \left(M I D_{A \rightarrow C}, M I D_{C \rightarrow B}\right)\right]
$$

Kemudian untuk menentukan keseimbangan kekuatan hubungan antar aktor, terlebih dahulu perlu menghitung pengaruh langsung dan tidak langsung dari aktor. Jika $M_{A}$ diartikan sebagai pengaruh total langsung dari aktor A terhadap yang lain, maka

$$
M_{A}=\sum_{B}\left(M I D I_{A, B}\right)-M I D I_{A, A}
$$

dan jika kita definisikan $D_{A}$ total pengaruh langsung dan tidak langsung yang diterima A dari aktor yang lain, sebagaimana persamaan berikut

$$
D_{A}=\sum_{B}\left(M I D I_{B, A}\right)-M I D I_{A, A}
$$

Selanjutnya koefisien keseimbangan kekuatan hubungan akan dihitung dengan rumus

$$
r_{A}=\left[\frac{\left(M_{A}-M I D I_{A, A}\right)}{\sum_{A}\left(M_{A}\right)}\right] x\left[\frac{M_{A}}{M_{A}+D_{A}}\right]
$$

Langkah selanjutnya, MACTOR akan menghitung matrik $3 \mathrm{MAO}$ yakni matrik yang menjadi dasar dan penting dalam pembahasan MACTOR, dengan formulasi sebagai berikut.

$$
3 M A O_{A, i}=2 M A O_{A, i} \times r_{A}
$$

Melalui matrik 3MAO dapat dihasilkan berbagai keistimewaan, antara lain koefisien mobilisasi yang menunjukkan aktor yang berbeda terlibat dalam satu situasi sebagaimana dijelaskan rumus berikut.

$$
\mathrm{Mob}_{A}=\sum|3 M A O|
$$

Persetujuan dan ketidaksetujuan atas suatu tujuan kemudian di overlay dengan menggunakan formula berikut.

$$
\begin{array}{r}
A g_{A}=\sum_{a}\left(3 M A O_{A, i}(3 M A O>0)\right) \\
D i s A g_{A}=\sum_{a}\left(3 M A O_{A, i}(3 M A O<0)\right)
\end{array}
$$

Keistimewaan lain yang juga dapat diolah dari matrik 3 MAO adalah matrik konvergensi (3CAA) yang menggambarkan seberapa besar para aktor setuju terhadap suatu isu dan divergensi (3DAA) yang menggambarkan sebaliknya atau ketidaksetujuan. Matrik konvergensi (persetujuan) dihasilkan melalui formula :

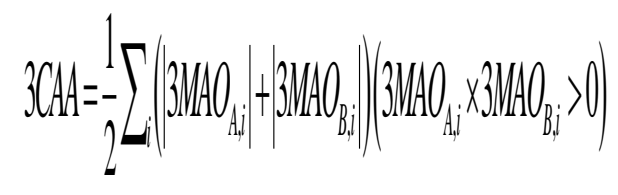

Sedangkan matrik divergensi (ketidaksetujuan) ditulis dengan formula : 


$$
\left.3 D A A=\frac{1}{2} \sum_{i}\left(\left|3 M A O_{A, i}\right|+3 M A O_{B, i}\right)\right)\left(3 M A O_{A, i} \times 3 M A O_{B, i}<0\right)
$$

Selanjutnya hasil perhitungan konvergensi dan devergensi antar aktor tersebut akan menghasilkan aktor akhir dari MACTOR yaitu koefisien ambivalen untuk setiap aktor yang dihitung dengan rumus :

$$
3 E Q_{i}=1-\left[\frac{\left(\sum_{k}\left\|3 C A A_{i, k}-3 D A A_{i, k}\right\|\right)}{\sum_{k}\left\|3 C A A_{i, k}+3 D A A_{i, k}\right\|}\right]
$$

Selain menggunakan pendekatan prospective analysis, penelitian ini juga merumuskan hasil FGD stakeholders yang terkait langsung dengan hilirisasi produk olahan berbahan baku karet di Provinsi Jambi, dalam memetakan tipologi klaster industri hilir berbahan baku karet. Stakeholders yang terlibat dalam FGD diantaranya OPD provinsi dan kabupaten yang terkait dengan hilirisasi karet yaitu Dinas Perkebunan, Dinas Pendustrian dan Perdagangan, Dinas Koperasi dan UKM, Bappeda, Balitbangda, Dinas Penanaman Modal Daerah dan Pelayanan Terpadu Satu Pintu. Stakeholders selanjutnya yaitu perguruan tinggi diwakili oleh Universitas Jambi dan Politeknik Jambi, petani karet, perusahaan crumb rubber, dan Gabungan Pengusaha Karet Jambi (Gapkindo).

FGD yang dilakukan dengan pendekatan seelig method yang dipopulerkan oleh Tina Seelig (2017) dan dikembangkan oleh Fauzi (2017). Pada saat pelaksanaan FGD, peserta dibagi dalam tiga kelompok yang membahas tiga topik permasalahan : 1. Isu-isu strategis terkait hilirisasi karet di Provinsi Jambi; 2. Memetakan tipologi klaster hilirisasi karet di Provinsi Jambi; Topik yang sama tersebut dibahas oleh masing-masing kelompok, dan diakhir FGD membuat konsensus dari semua peserta FGD tentang topik yang dibahas, sehingga menghasilkan isu yang konvergen secara delfi.

\section{HASIL DAN PEMBAHASAN}

Analisis klaster dilakukan berdasarkan definisi operasional secara umum yang dikemukan oleh Poter (1998), yaitu klaster industri sebagai kosentrasi geografis dari subsektor manufaktur yang sama. Pada tulisan ini, hasil rumusan FGD dalam penentuan klaster telah diuji variabel kuncinya dengan prospective analisis. FGD stakeholders menghasilkan tiga tipologi klaster hilirisasi karet yaitu Tipologi HVLV (Hight Volume and Low Volume), Tipologi EMLM (Export and Local markets), dan Tipologi HMLM (High and Low Mulplier Effects). Tiga tipolagi klaster yang dihasilkan secara umum berdasarkan jenis produk berbahan baku olahan karet sebagaimana berikut. Tipologi klaster produk hilirisasi karet HVLV dapat dilihat pada Gambar 1. 


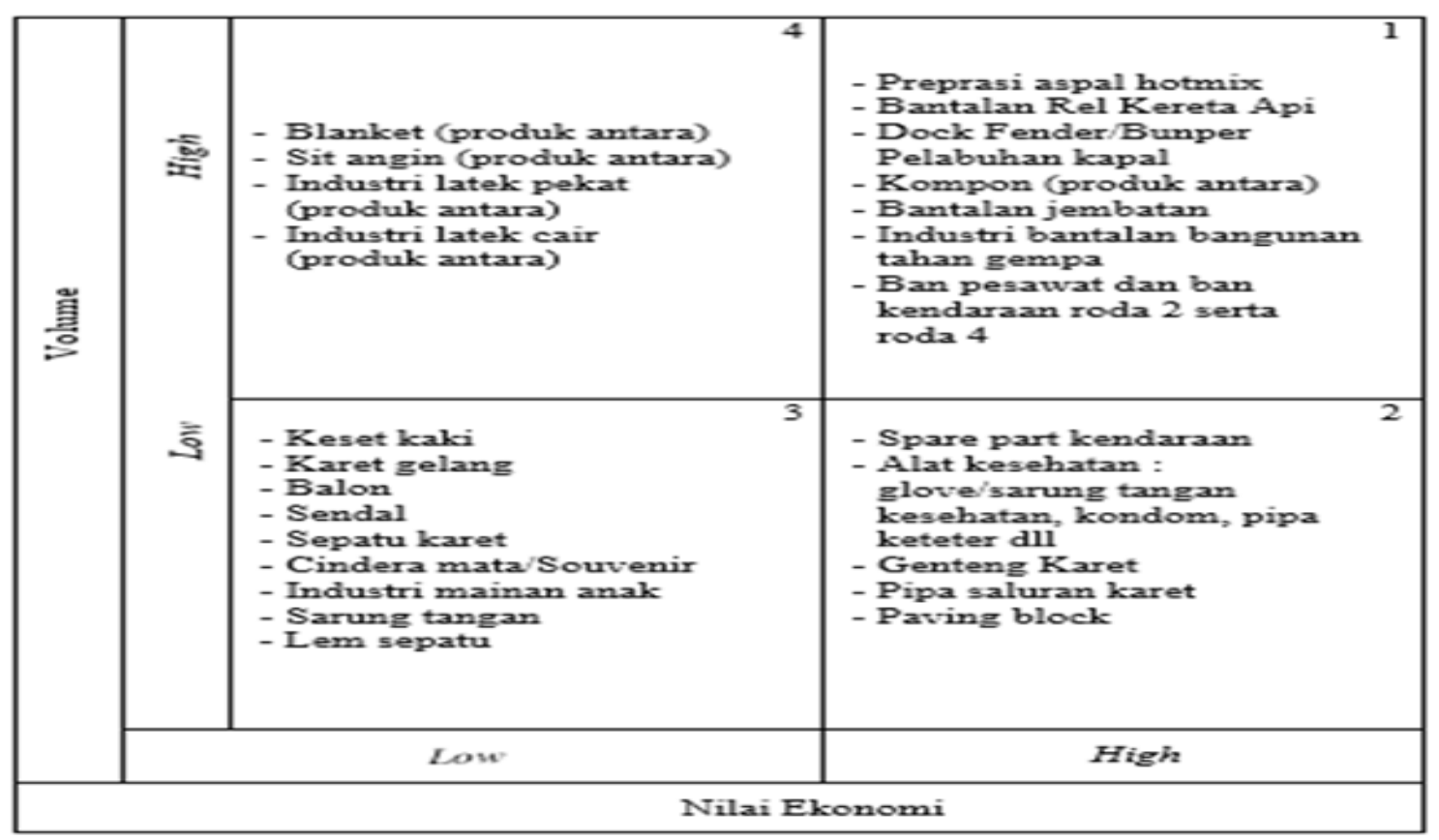

Gambar 1 Tipologi klaster produk hilirisasi karet HVLV

Tipologi Klaster HVLV (High and Low Volume) pada Gambar 1 mengklaster produk hilirisasi karet berdasarkan volume dan nilai ekonomi. Dimana tinggi dan rendah volume bahan baku karet dikuadrankan dengan tinggi dan rendahnya nilai ekonomi produk yang dihasilkan.

\section{Kuadran 1 Klaster HVLV mewakili} produk karet yang pembuatannya mengunakan volume bahan baku tinggi, dan ketika telah di produksi menghasilkan produk yang bernilai ekonomi tinggi pula. Produk yang di kategorikan masuk di kuadran 1 Klaster HVLV diantaranya : aspal karet hotmix, bantalan rel kereta api, dock fenderl bunper pelabuhan kapal, kompon (produk antara), bantalan jembatan, bantalan bangunan anti gempa, ban pesawat dan ban kendaraan roda 2 serta roda 4 . Kemudian produk hilir karet yang berada di kuadran 2 Klaster HVLV adalah mewakili produk karet yang pembuatannya mengunakan volume bahan baku yang rendah, namun ketika telah di produksi menghasilkan produk yang bernilai ekonomi tinggi. Produk yang dikategorikan pada kudran 2 Klaster HVLV diantaranya : spare part kendaraan, souvenir, balon, alat kesehatan (glove/sarung tangan, kondom, pipa keteter dII), genteng karet, pipa saluran karet. Produk hilir karet yang berada di kuadran 3 Klaster HVLV adalah mewakili produk karet yang pembuatannya mengunakan volume bahan baku yang rendah, dan ketika telah di produksi menghasilkan produk yang bernilai ekonomi yang tinggi pula. Produk pada kuadran 3 Klaster HVLV diantaranya keset kaki, gelang karet, balon, sandal, sepatu karet, souvenir, mainan anak-anak, sarung tngan karet, dan lem sepatu. Terakhir kuadran 4 Klaster HVLV 
merupakan produk karet yang pembuatannya mengunakan volume bahan baku yang tinggi, namun ketika telah di produksi menghasilkan produk yang bernilai ekonomi rendah.

Berikut pada Gambar 2 adalah Tipologi Klaster EMLM atau klaster berdasarkan pasar yaitu pasar ekspor atau pasar lokal yang dikuadrankan dengan nilai ekonominya. Pada Klaster EMLM yang berada pada kuadran 1 merupakan produk yang memiliki jangkauan pasar ekspor dan bernilai ekonomi tinggi. Produk kategori kuadran 1 klaster Klaster EMLM diantaranya perahu karet, ban pesawat, ban alat berat, pipa saluran karet, sealer hidrolik, pelindung kabel, gabus penahan benturan dari karet, paving block (konblock lantai karet), dan aspal karet hotmix. Kuadran 2 Klaster EMLM merupakan produk hilir karet dengan jangkauan pasar lokal, namun memiliki nilai ekonomi yang tinggi. Dintara produk yag tergolong di kuadran 2 Klaster EMLM yaitu ban vulkanisir, karet aspal hotmik, bantalan jembatan, sit angin, dock fender, latek pekat, gladak kapal, kondom. Kuadran 3 Klaster EMLM adalah produk yang jangkauan pasar lokal dan memiliki nilai ekonomi yang rendah. Produk yang berada pada kuadran 3 klaster B diantaranya karet gelang, sol sepatu, asesoris, balon, bokar, vulkanisir ban, lem sepatu, spare park kendaraan bermotor, sabutret. Kuadran 4 Klaster EMLM adalah produk yang memiliki jangkauan pasar ekspor, namun nilai ekonominya rendah diantaranya sepatu karet, asesoris, karpet karet, crumb rabber, glove, SIR 20, dan bola kaki.

\begin{tabular}{|c|c|c|c|}
\hline \multirow[t]{3}{*}{ 岂 } & 总 & $\begin{array}{l}\text { - Sepatu karet } \\
\text { - Aksesoris } \\
\text { - Karpet Karet } \\
\text { - Crumb rubber } \\
\text { - Glove/sarumg tangan } \\
\text { - SIR } 20 \\
\text { - Bola kaki }\end{array}$ & $\begin{array}{l}\text { - Perahu karet } \\
\text { - Ban pesawat } \\
\text { - Ban alat berat } \\
\text { - Pipa saluran karet } \\
\text { - Sealer Hidrolik } \\
\text { - Pelindung kabel } \\
\text { - Gabus penahan benturan dari } \\
\text { bahan karet } \\
\text { - Paring blok (konblok lantai } \\
\text { karet) } \\
\text { - Aspal karet }\end{array}$ \\
\hline & 晃 & $\begin{array}{l}\text { - Karet gelang } \\
\text { - Sol sepatu } \\
\text { - aksesoris } \\
\text { - Balon } \\
\text { - Bolcar } \\
\text { - Vulkanisir ban } \\
\text { - Lem } \\
\text { - Produk UMrKM } \\
\text { - Spare part kendaraan } \\
\text { bermotor } \\
\text { - Sabutret }\end{array}$ & $\begin{array}{l}\text { - Ban Vulkanisis } \\
\text { - Karet aspal } \\
\text { - Bantalan jembatan } \\
\text { - Sheet angin } \\
\text { - Latek pekat } \\
\text { - Geladak kapalsandaram } \\
\text { kapal } \\
\text { - Kondom }\end{array}$ \\
\hline & \multicolumn{3}{|r|}{ High } \\
\hline
\end{tabular}

Gambar 2 Tipologi klaster produk hilirisasi karet EMLM 
Tipologi Klaster HMLM yang memetakan produk hilir karet berdasarkan multiplier effect yang dikudrankan dengan nilai ekonominya. Kuadran 1 Klaster HMLM merupakan produk yang memberikan multipler tinggi dan memberikan nilai ekonomi yang tinggi, diantaranya aspal karet, latek pekat, karet pengahapus, sit angin, karet gelang, chasing HP, alat kesehatan dari karet, dan pelindung kabel. Kuadran 2 Klaster HMLM adalah produk hilir karet yang memiliki multiplier effect rendah, namun nilai ekonominya tinggi diantara produknya yaitu ban pesawat, bahan baku kerajinan, umpan pancing dan karet wrap. Kuadran 3 Klaster HMLM merupakan produk yang memiliki multiplier rendah dan nilai ekonomi yang rendah pula diantaranya bokar, alat sedot, dan chasing/pelindung HP. Kuadran 4 Klaster HMLM menunjukkan produk yang memiliki multiplier effect tinggi namun nilai ekonominya rendah diantaranya aksesoris, balon, karet gelang, peralatan rumah tangga, marka jalan, campuran aspal karet hotmix, bantalan kereta, dan roda kereta dorong/lori. Tipologi klaster produk hilirisasi karet HMLM dapat dilihat pada Gambar 3.

\begin{tabular}{|c|c|c|c|}
\hline \multirow{3}{*}{ 兽 } & \multirow{2}{*}{$\begin{array}{l}\text { 흥 } \\
\text { 흠 }\end{array}$} & $\begin{array}{l}\text { - Aksesoris } \\
\text { - Balon } \\
\text { - Karet gelang } \\
\text { - Peralatan Rumah tangga } \\
\text { - Marka jalan } \\
\text { - Campuran aspal } \\
\text { - Bantalan rel kereta } \\
\text { - Ban kereta dorong (lori) }\end{array}$ & $\begin{array}{l}\text { - Aspal karet } \\
\text { - Latek pelcat } \\
\text { - Karet penghapus } \\
\text { - Sheet angin } \\
\text { - Karet gelang } \\
\text { - Chasing HP } \\
\text { - Alat kesehatan dari karet } \\
\text { - Aspal/jalan karet } \\
\text { - Pelindung kabel }\end{array}$ \\
\hline & & $\begin{array}{l}\text { - Bolkar } \\
\text { - Alat sedot karet } \\
\text { - Pelindung HP }\end{array}$ & $\begin{array}{l}\text { - Ban Pesawat } \\
\text { - Bahan baku kerajinan tangan } \\
\text { - Umpan pancing } \\
\text { - Karet wrap }\end{array}$ \\
\hline & & Low & High \\
\hline & \multicolumn{3}{|c|}{ Nilai Ekonomi } \\
\hline
\end{tabular}

Gambar 3 Tipologi klaster produk hilirisasi karet HMLM

Ketiga tipologi klaster diatas akan dijadikan dasar dari menentukan klaster hilirisasi karet berdasarkan produk dan wilayahnya di Provinsi Jambi. Tentunya dalam memetakan klaster industri hilir karet di Provinsi Jambi tidak terlepas dari indikaror teori klaster, diantaranya pendekatan teori competitive advantage (Porter 1990), yang menentukan daya saing suatu klaster diantaranya didukung oleh ketersedian bahan baku, infrastruktur, dukungan industri lainnya, dan dukungan pemerintah.

Selanjutnya hasil prospective analisis yang menggunakan tools MACTOR 
menunjukkan ketergantungan antar aktor Provinsi Jambi yang akan diuraikan melalui dalam melaksanakan hilirisasi karet di Tabel 1 berikut.

Tabel 1 Matrik pengaruh dan ketergantungan antar aktor

\begin{tabular}{|c|c|c|c|c|c|c|c|c|c|c|c|c|c|}
\hline MDII & $\begin{array}{l}\text { 윰 } \\
\text { 응 } \\
\text { 뭉 }\end{array}$ & 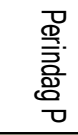 & $\begin{array}{l}\frac{}{0} \\
\frac{N}{O} \\
0 \\
0\end{array}$ & 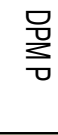 & $\begin{array}{l}\text { 믐 } \\
\text { 믄 } \\
\frac{\text { ㅁ }}{x}\end{array}$ & 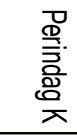 & 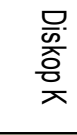 & 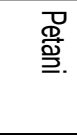 & $\begin{array}{l}\text { 号 } \\
\text { 品 }\end{array}$ & 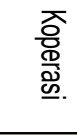 & ס & $\begin{array}{l}\overrightarrow{\text { D्D }} \\
\stackrel{ }{\bar{C}} \\
\frac{\bar{C}}{\bar{N}}\end{array}$ & $=$ \\
\hline Disbun Pro & 7 & 7 & 10 & 7 & 12 & 10 & 11 & 12 & 9 & 8 & 12 & 4 & 102 \\
\hline Perindag $P$ & 8 & 7 & 11 & 8 & 12 & 15 & 14 & 13 & 10 & 11 & 13 & 5 & 120 \\
\hline Diskop P & 8 & 7 & 11 & 9 & 11 & 11 & 14 & 13 & 12 & 10 & 12 & 7 & 114 \\
\hline DPM P & 7 & 7 & 8 & 6 & 10 & 10 & 10 & 11 & 10 & 7 & 9 & 5 & 94 \\
\hline Disbun K & 6 & 4 & 7 & 6 & 8 & 8 & 8 & 7 & 8 & 5 & 7 & 4 & 70 \\
\hline Perindag K & 6 & 4 & 5 & 4 & 7 & 7 & 7 & 7 & 7 & 5 & 7 & 4 & 63 \\
\hline Diskop K & 8 & 8 & 11 & 8 & 12 & 13 & 14 & 13 & 12 & 10 & 13 & 6 & 114 \\
\hline Petani & 5 & 4 & 5 & 4 & 6 & 6 & 6 & 6 & 6 & 4 & 6 & 4 & 56 \\
\hline UPPB & 10 & 9 & 13 & 10 & 16 & 15 & 17 & 15 & 11 & 15 & 14 & 4 & 138 \\
\hline Koperasi & 12 & 9 & 17 & 14 & 16 & 17 & 21 & 16 & 15 & 15 & 16 & 5 & 158 \\
\hline PCR & 6 & 7 & 7 & 5 & 10 & 11 & 10 & 15 & 11 & 9 & 11 & 6 & 97 \\
\hline Tengkulak & 6 & 4 & 8 & 7 & 9 & 9 & 9 & 12 & 9 & 8 & 7 & 5 & 88 \\
\hline Di & 82 & 70 & 102 & 82 & 121 & 125 & 127 & 134 & 109 & 92 & 116 & 54 & 1214 \\
\hline
\end{tabular}

Tabel 1 di atas menunjukkan bahwa stakeholder yang memiliki pengaruh yang tinggi adalah koperasi dengan skor 158 disusul kemudian dengan UPPB, sementara stakeholder yang memiliki kecenderung ketergantungan tinggi adalah petani karet dengan skor 134 dan yang terendah adalah tengkulak dengan skor 54. Penjelasan ini juga terlihat pada Gambar 5 berikut yang memetakan stakeholder pada kuadran pengaruh dan ketergantungan.

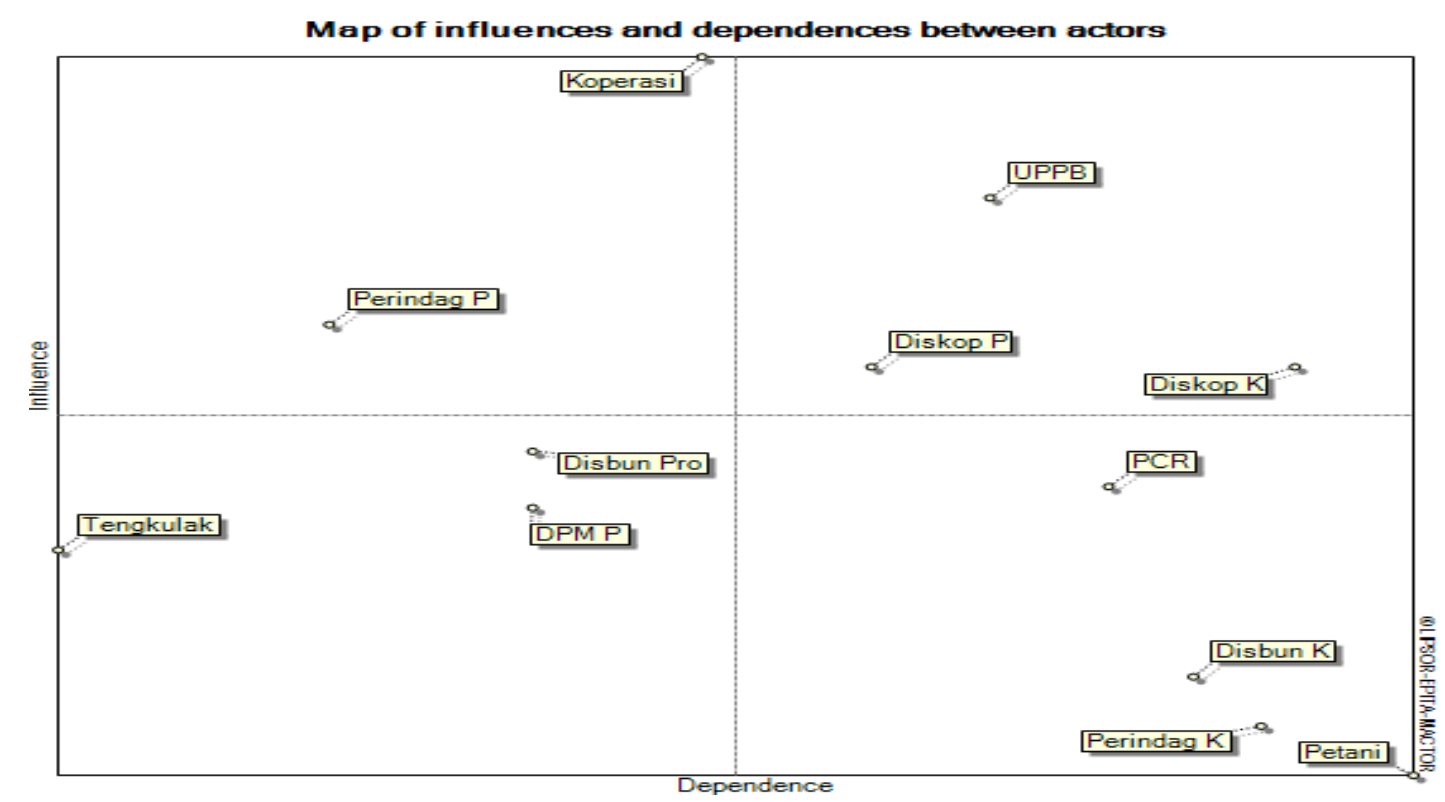

Gambar 4 Pemetaan aktor hilirisasi dalam kuadran pengaruh dan dependensi

Sebagamana terlihat pada Gambar 5 bahwa Dinas Koperasi dan Dinas Perindag Provinsi Jambi berada pada kuadra I (kiri atas) dengan pengaruh tinggi dan ketergantungan rendah. Sebaliknya adalah kuadran 3 (kanan bawah) dimana petani 
memiliki tingkat ketergantungan yang tinggi dan pengaruh yang sangat kecil. Pada Kuadaran 4 (kiri bawah) adalah tengkulak yang memiliki pengaruh namun memeiliki ketergantungan yang sangat kecil. Hal ini dapat difahami karena memang tengkulak cenderung bersifat independen namun memilki pengaruh meski tidak terlalu kuat pada stakeholder yang lain.

Tabel 2 berikut ini menyajikan derajat mobilisasi antara stakeholder dengan tujuan hilirisasi.

Tabel 2 Derajat mobilisasi stakeholder-tujuan

\begin{tabular}{|c|c|c|c|c|c|c|c|c|c|}
\hline ЗMAO & $\begin{array}{l}\text { 믐 } \\
\text { 못 }\end{array}$ & $\begin{array}{l}\text { 马 } \\
\text { 品 } \\
\text { 邑 } \\
\text { 足 }\end{array}$ & 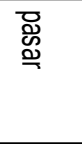 & $\begin{array}{l}\text { 종 } \\
\text { 응 } \\
\text { 읏 }\end{array}$ & 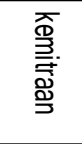 & $\begin{array}{l}\text { 끗 } \\
\text { 음 } \\
\text { 으‥ }\end{array}$ & 것 & 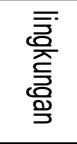 & $\begin{array}{l}\text { 음 } \\
\text { 을: } \\
\text { 응. }\end{array}$ \\
\hline Disbun Pro & 3.3 & 3.3 & 3.3 & 2.2 & 3.3 & 3.3 & 3.3 & 2.2 & 23.9 \\
\hline Perindag $\mathrm{P}$ & 2.9 & 2.9 & 4.4 & 4.4 & 4.4 & 2.9 & 2.9 & 2.9 & 28.0 \\
\hline Diskop P & 3.4 & 2.2 & 2.2 & 2.2 & 3.4 & 3.4 & 2.2 & 2.2 & 21.3 \\
\hline DPM P & 1.9 & 1.9 & 2.9 & 2.9 & 3.9 & 3.9 & 3.9 & 2.9 & 24.3 \\
\hline Disbun K & 1.9 & 1.9 & 1.4 & 1.4 & 1.9 & 1.4 & 1.4 & 1.4 & 12.7 \\
\hline Perindag K & 1.2 & 1.2 & 0.8 & 1.2 & 1.6 & 1.6 & 1.6 & 0.8 & 9.7 \\
\hline Diskop K & 2.9 & 2.0 & 2.0 & 2.0 & 3.9 & 3.9 & 2.9 & 2.0 & 21.5 \\
\hline Petani & 1.2 & 0.0 & 0.6 & 0.6 & 0.9 & 0.0 & 0.6 & -0.3 & 4.3 \\
\hline UPPB & 5.9 & 1.5 & 5.9 & 5.9 & 5.9 & 2.9 & 5.9 & 2.9 & 36.6 \\
\hline Koperasi & 7.5 & 5.6 & 7.5 & 5.6 & 7.5 & 7.5 & 5.6 & 3.7 & 50.4 \\
\hline PCR & 1.6 & 0.8 & 1.6 & 2.4 & 1.6 & 1.6 & 1.6 & -1.6 & 12.9 \\
\hline Tengkulak & -2.1 & -2.1 & 1.1 & 1.1 & -3.2 & -2.1 & -2.1 & -2.1 & 15.9 \\
\hline Number of agreements & 33.7 & 23.3 & 33.6 & 31.8 & 38.1 & 32.4 & 31.9 & 21.1 & \\
\hline Number of disagreements & -2.1 & -2.1 & 0.0 & 0.0 & -3.2 & -2.1 & -2.1 & -4.0 & \\
\hline Degree of mobilisation & 35.8 & 25.4 & 33.6 & 31.8 & 41.3 & 34.5 & 34.1 & 25.1 & \\
\hline
\end{tabular}

Tabel 2 di atas stakeholder yang memiliki skor mobilisasi tertinggi adalah koperasi (50.4) disusul kemudian dengan UPPB (36.6) dan Perindap Provinsi. Artinya bahwa menyangkut hilirisai karet ketiga stakeholder ini merupakan stakeholder yang akan aktif dalam menjawab permasalah hilirisasi karet di Jambi. Derajat mobilisi (baris bawah) menujjukkan tujuan mana yang diperkirakan akan menjadi isu utama yang memancing reaksi stakeholder. Dalam kasus ini tujuan kemitraan dengan skor 41.3 merupakan tujuan yang dianggap penting oleh para actor disusul kemudian dengan peningkatan pendapatan petani karet (PPPK) dengan skor 35,8 dan peningkatan akses pasar dengan skor 33,6. Ketiga tujuan tersebut dianggap penting oleh para stakeholder untuk meningkatkan hilirisasi kareat di Jambi.

Gambar 5 di bawah ini menggambarkan daya saing aktor yang ditunjukkan oleh tingkat pengaruh langsung dan tidak langsung actor tersebut terhadap aktor lainnya. Dari Gambar 5 dijelaskan bahwa aktor yang berperan penting baik langsung maupun tidak langung adalah koperasi dengan skor daya saing 1,9 disusul kemudian dengan UPPB dan Dinas perindustrian denga skor masing-masing sebesar 1,5. Sementara actor yang memiliki daya saing lemah adalh petani karet dengan skor 0.3 Hal ini dapat difahami karena posisi petani karet yang cenderung pada kuadran 3 (kanan bawah) yakni posisi sebagai aktor terdampak dari kebijakan hilirisasi karet. 
Histogram of MDII's competitiveness

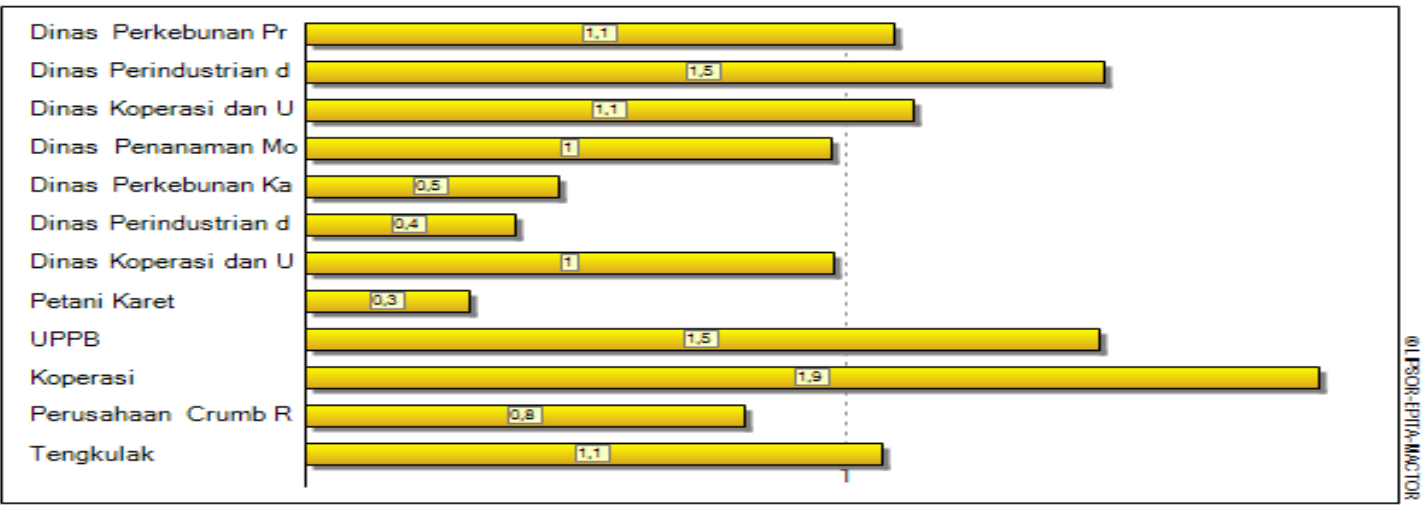

Gambar 5 Daya saing aktor dalam hilirisasi karet

Tabel 3 Matrik Konvergensi antar aktor

\begin{tabular}{|c|c|c|c|c|c|c|c|c|c|c|c|c|}
\hline 1CAA & 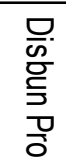 & 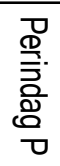 & $\begin{array}{l}\text { 믐 } \\
\text { 음 } \\
\text { ত }\end{array}$ & $\underset{0}{\stackrel{0}{\underline{0}}}$ & $\begin{array}{l}\frac{}{0} \\
\text { 은 } \\
\frac{1}{x}\end{array}$ & 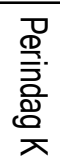 & $\begin{array}{l}\text { 음 } \\
\text { 응 } \\
\text { 줏 }\end{array}$ & 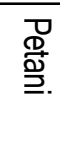 & $\begin{array}{l}\subsetneq \\
\text { 号 }\end{array}$ & 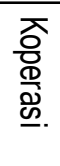 & $\begin{array}{l}\text { D } \\
\text { D }\end{array}$ & 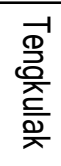 \\
\hline Disbun Pro & 0 & 8 & 8 & 8 & 8 & 8 & 8 & 5 & 8 & 8 & 7 & 2 \\
\hline Perindag $\mathrm{P}$ & 8 & $\overline{0}$ & 8 & 8 & 8 & 8 & 8 & 5 & 8 & 8 & 7 & 2 \\
\hline Diskop P & 8 & 8 & $\overline{0}$ & 8 & 8 & 8 & 8 & 5 & 8 & 8 & 7 & 2 \\
\hline DPM P & 8 & 8 & 8 & 0 & 8 & 8 & 8 & 5 & 8 & 8 & 7 & 2 \\
\hline Disbun $\mathrm{K}$ & 8 & 8 & 8 & 8 & 0 & 8 & 8 & 5 & 8 & 8 & 7 & 2 \\
\hline Perindag K & 8 & 8 & 8 & 8 & 8 & 0 & 8 & 5 & 8 & 8 & 7 & 2 \\
\hline Diskop K & 8 & 8 & 8 & 8 & 8 & 8 & 0 & 5 & 8 & 8 & 7 & 2 \\
\hline Petani & 5 & 5 & 5 & 5 & 5 & 5 & 5 & 0 & 5 & 5 & 6 & 3 \\
\hline UPPB & 8 & 8 & 8 & 8 & 8 & 8 & 8 & 5 & 0 & 8 & 7 & 2 \\
\hline Koperasi & 8 & 8 & 8 & 8 & 8 & 8 & 8 & 5 & 8 & $\overline{0}$ & 7 & 2 \\
\hline PCR & 7 & 7 & 7 & 7 & 7 & 7 & 7 & 6 & 7 & 7 & 0 & 3 \\
\hline Tengkulak & 2 & 2 & 2 & 2 & 2 & 2 & 2 & 3 & 2 & 2 & 3 & 0 \\
\hline Number of convergences & 78 & 78 & 78 & 78 & 78 & 78 & 78 & 54 & 78 & 78 & 72 & 24 \\
\hline
\end{tabular}

Kecenderungan konvergensi ini juga yang merupakan penjabaran grafis dari dapat dilihat pada Gambar 6 di bawah ini Tabel 3 di atas.

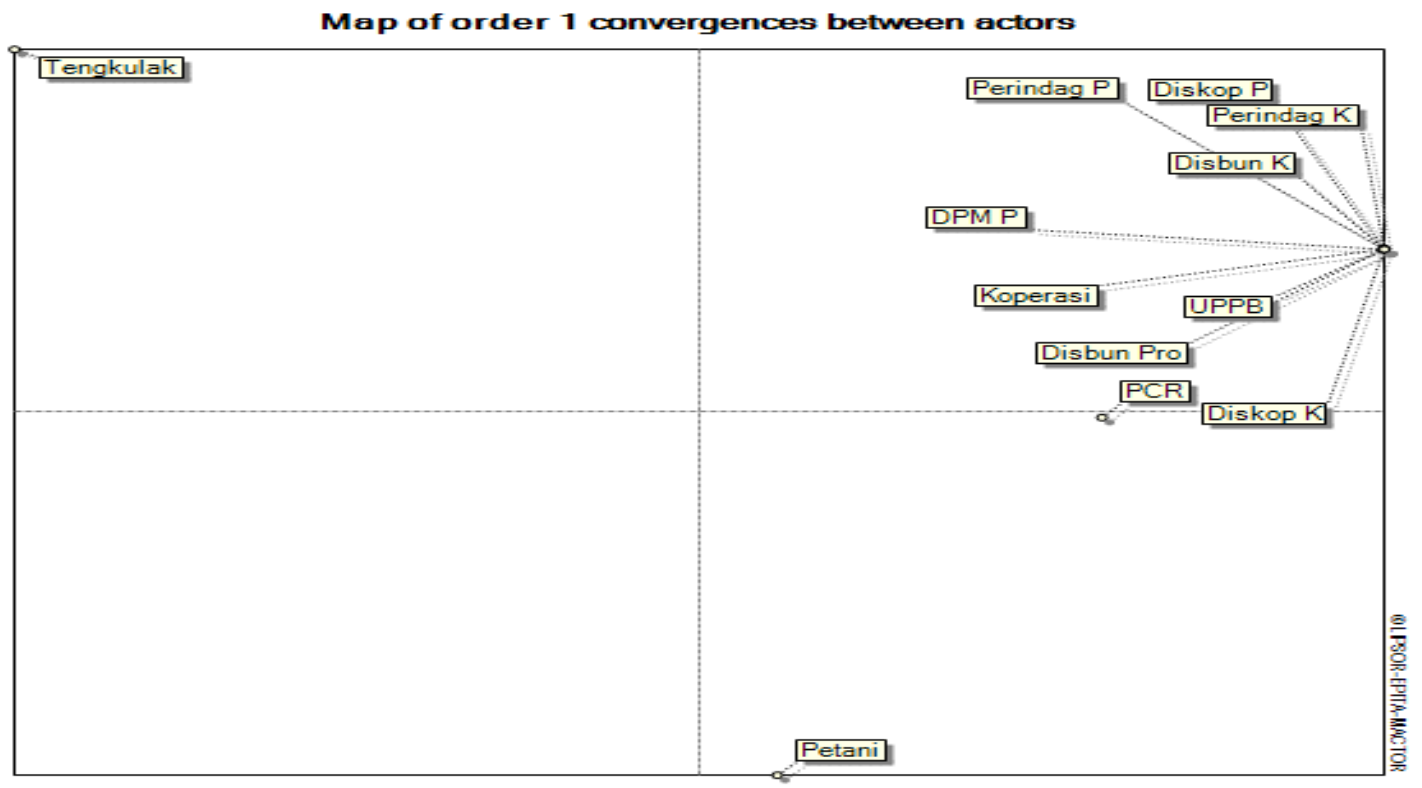




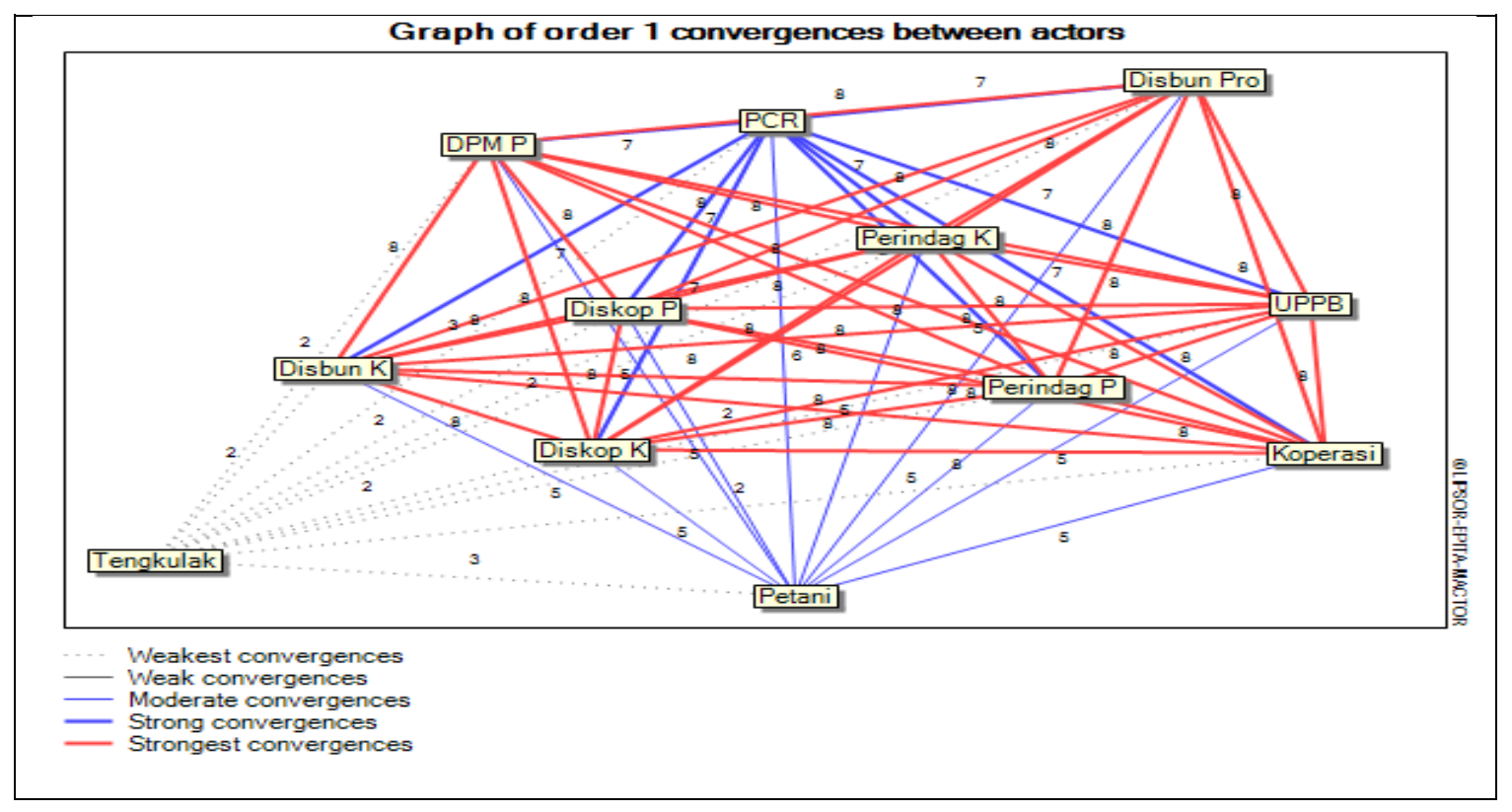

Gambar 6 Konvergensi antara aktor

Gambar 6 menunjukkan konvergensi dengan stakeholder lainnya, sementara beberapa stakeholder, dimana derajat sebagian besar stakeholder pemerintah konvergensi yang tinggi misalnya tengkulak cendering memiliki skor divergensi yang dengan skor 62. Artinya bahwa tengkulak rendah yang artinya kecenderungan konflik memiliki kepentingan yang sangat berbeda di antara Lembaga ini relatif kecil.

Tabel 4 Matrik divergensi antar aktor

\begin{tabular}{|c|c|c|c|c|c|c|c|c|c|c|c|c|}
\hline 1DAA & $\begin{array}{l}\frac{0}{0} \\
\stackrel{5}{5} \\
5 \\
0 \\
0 \\
0\end{array}$ & 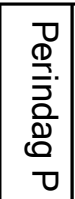 & $\begin{array}{l}\frac{\square}{0} \\
\frac{\omega}{\hat{O}} \\
\frac{0}{0} \\
0\end{array}$ & $\begin{array}{l}0 \\
0 \\
\frac{0}{3} \\
0\end{array}$ & 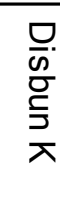 & 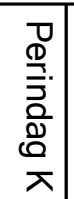 & $\begin{array}{l}\frac{\square}{Q} \\
\frac{D}{\hat{O}} \\
\frac{0}{\lambda}\end{array}$ & $\begin{array}{l}\text { D. } \\
\stackrel{\mathbb{D}}{D} \\
\underline{D}\end{array}$ & 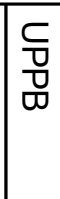 & 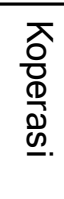 & $\begin{array}{l}\bigcap_{D} \\
\text { D. }\end{array}$ & 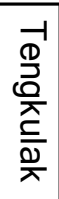 \\
\hline Disbun Pro & 0 & 0 & 0 & 0 & 0 & 0 & 0 & 1 & 0 & 0 & 1 & 6 \\
\hline Perindag P & 0 & 0 & 0 & 0 & 0 & 0 & 0 & 1 & 0 & 0 & 1 & 6 \\
\hline Diskop P & 0 & 0 & 0 & 0 & 0 & 0 & 0 & 1 & 0 & 0 & 1 & 6 \\
\hline DPM P & 0 & 0 & 0 & 0 & 0 & 0 & 0 & 1 & 0 & 0 & 1 & 6 \\
\hline Disbun K & 0 & 0 & 0 & 0 & 0 & 0 & 0 & 7 & 0 & 0 & 1 & 6 \\
\hline Perindag K & 0 & 0 & 0 & 0 & 0 & 0 & 0 & 1 & 0 & 0 & 1 & 6 \\
\hline Diskop K & 0 & 0 & 0 & 0 & 0 & 0 & 0 & 1 & 0 & 0 & 1 & 6 \\
\hline \begin{tabular}{|l} 
Petani \\
\end{tabular} & 1 & 1 & 1 & 1 & 1 & 1 & 1 & 0 & 1 & 1 & 0 & 3 \\
\hline UPPB & 0 & 0 & 0 & 0 & 0 & 0 & 0 & 1 & 0 & 0 & 1 & 6 \\
\hline Koperasi & 0 & 0 & 0 & 0 & 0 & 0 & 0 & 1 & 0 & 0 & 1 & 6 \\
\hline PCR & 1 & 1 & 1 & 1 & 1 & 1 & 1 & 0 & 1 & 1 & 0 & 5 \\
\hline Tengkulak & 6 & 6 & 6 & 6 & 6 & 6 & 6 & 3 & 6 & 6 & 5 & 0 \\
\hline Number of divergences & 8 & 8 & 8 & 8 & 8 & 8 & 8 & 12 & 8 & 8 & 14 & 62 \\
\hline
\end{tabular}

Tabel 4 menunjukkan besarnya tinggi (6) dengan aktor lainnya. Penjelasan divergensi atau ketidaksesuaian antara ini dapat terlihat jelas pada Gambar 7 dan aktor. Dimana pada matrik diatas tengkulak berikut. memiliki angka ketidaksesuaian yang paling 


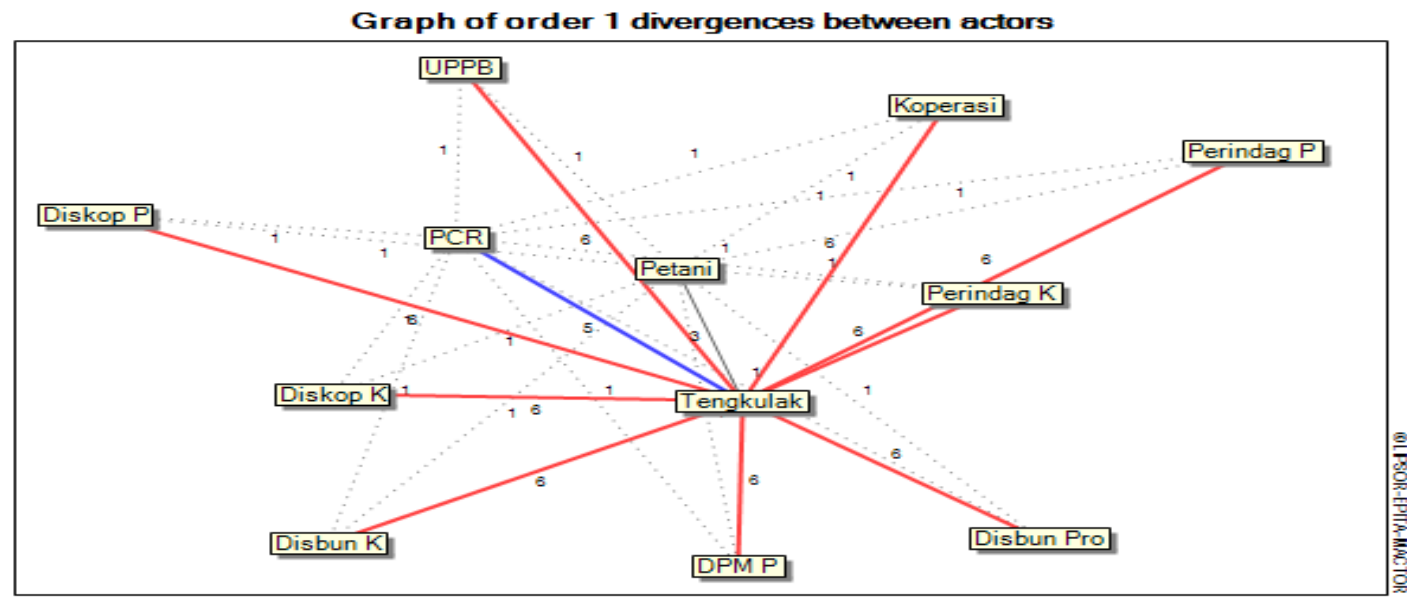

Weakest divergences

Moak divergences

Strong divergences

Strongest divergences

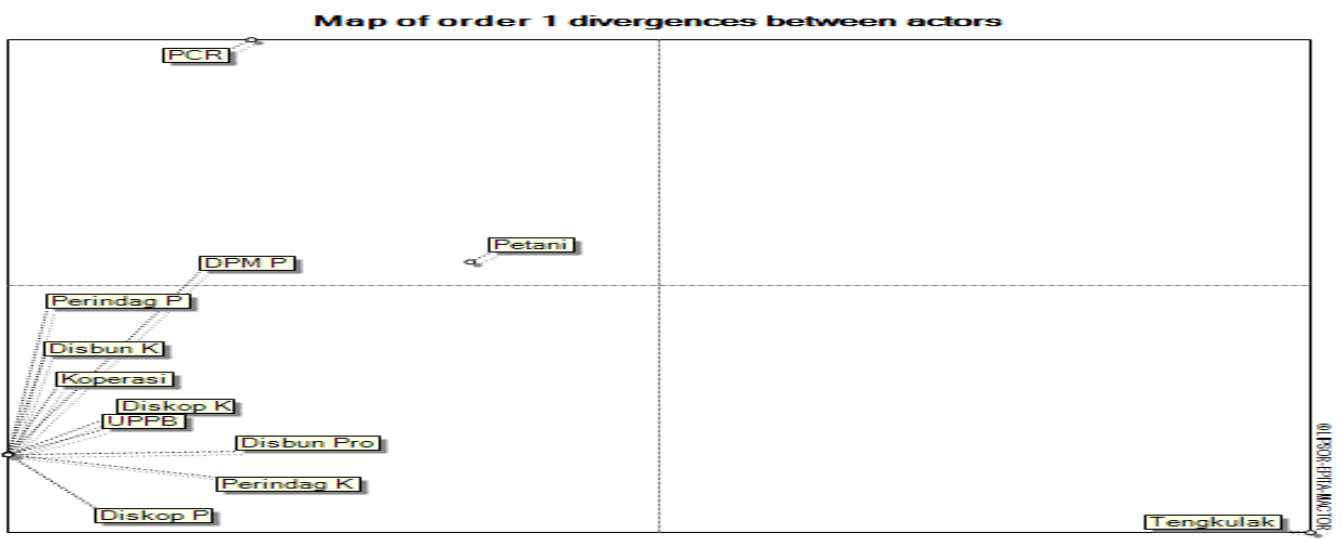

Gambar 7 Arah dan besar divergensi antar aktor Jarak kepentingan antar actor dan tujuan

Gambar 8 berikut ini menyajikan yang menggambarkan seberapa jauh atau "jarak" antar actor terhadap aktor lainnya dekat aktor tersebut dapat bekerja sama.

Graph of net distances between actors

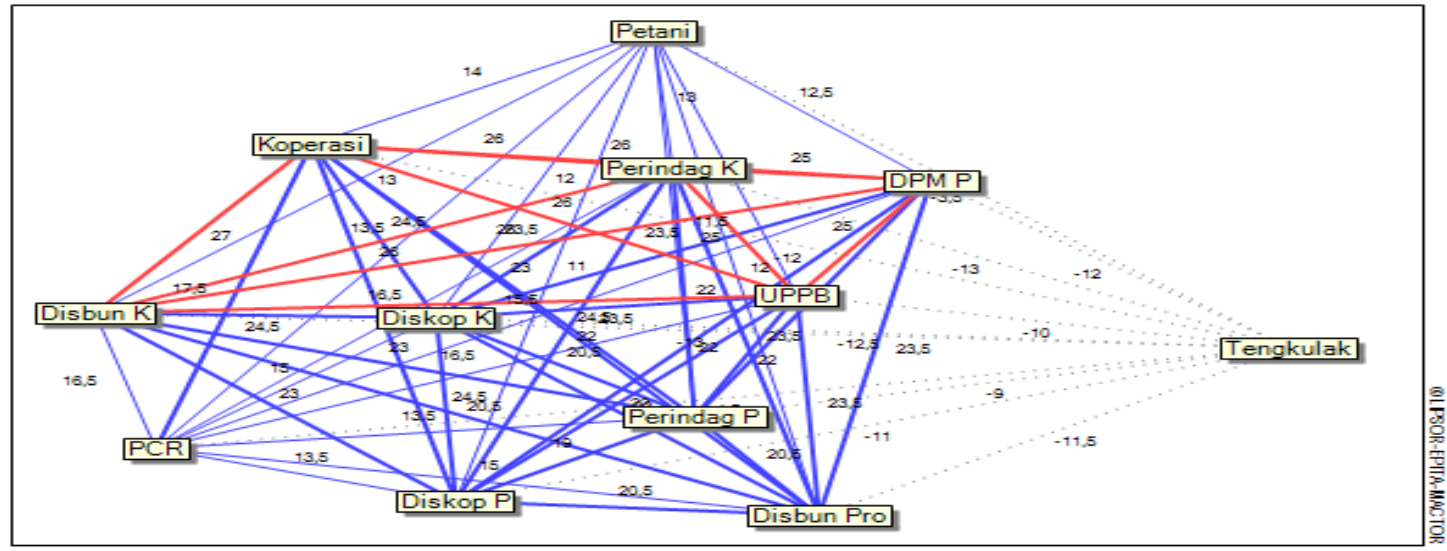

Shortest net distances

Short net distances

Moderate nistancet

Long net distances

Gambar 8 "jarak" antar aktor 
Gambar 8 di atas nampak bahwa stakeholder koperasi, disbun kabupaten UPPB memiliki jarak kepentingan yang dekat satu sama lain yang berarti bahwa kemungkinan kerja sama diantara Lembaga tersebut sangat kuat. Stakeholder lainnya juga memiliki jarak yang dekat kecuali tengkulak yang cenderung memiliki kepentingan yang berbeda.

Gambar 9 berikut ini menggambarkan seberapa jauh atau dekat antara aktor (stakeholder) dengan tujuan hilirisasi.
Gambar ini menujukkan kluster aktor dengan tujuan dimana tujuan PDRB, lingkugan, ekonomi dan pasar berada pada kuadran 1 dengan aktornya dalah Lembagalembaga pemerintah. Sementara tujuan kemitraan, pendapatn petani dantenaga kerja berada kuadran 4 dengan aktornya masing-masing petani, koperasi, UPPB dan PCR. Aktor tengkulak berada pada kluster tersendiri yang menunjukkan ketidak setujuan aktor ini terhadap tujuan yang berkaitan dengan hilirisasi.

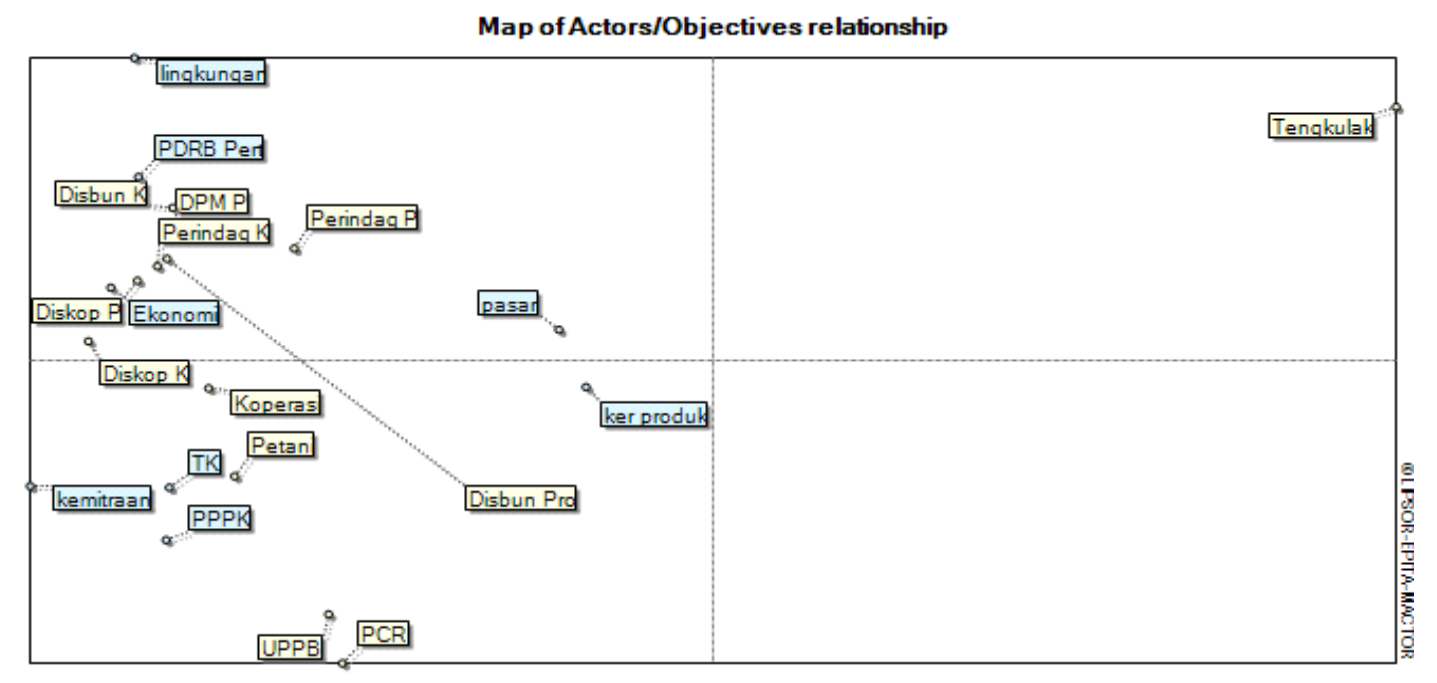

\section{KESIMPULAN}

Kegiatan hilirisasi karet telah dilaksanakan di Provinsi Jambi sejak tahun 2012. Hal ini dimulai dengan bergulirnya bantuan hilirisasi karet berupa mesin pengolahan karet yang diberikan oleh kementerian perindustrian RI. Berbagai usaha juga telah dilakukan oleh Pemerintah Provinsi Jambi untuk melakukan pendampingan hilirisasi karet di Provinsi Jambi melalui dinas teknis terkait, berupa pelatihan dan bantuan modal untuk penguatan aspek hulu dan hilir. Pada beberapa kabupaten di Provinsi Jambi juga telah melaksanakan hilirisasi karet, namun proses hilirisasi itu belum berjalan dengan optimal. Berdasarkan temuan dilapangan, bahwa dalam pelaksaannya hilirisasi karet dan di overlay dengan prospective analisis, dapat disimpulkan bahwa hilirisasi karet di Provinsi Jambi masih terkendala berbagai masalah yakni : volatilitas harga karet, kesiapan sumber daya manusia dalam melaksanakan hilirisasi karet atau perlunya 
peningkatan pelatihan sumber daya manusia, terbatasnya jangkauan pemasaran produk karet, profitabilitas produk olahan karet, masih perlunya peningkatan kemitraan dalam meraih modal dalam memproduksi produk karet, perlu dukungan regulasi pemerintah dalam mengatasi risiko yang akan dihadapi para pelaku hilirisasi karet, dan perlunya standarisasi produk karet. Disamping itu perlu pula diantisipasi konversi lahan karet kepada lahan sawit akibat harga karet yang selalu berfluktuasi dan tidak memihak kepada petani. Artinya, bahwa hilirisasi perlu diintegrasikan antara hulu, proses, dan hilir.

Penelitian ini menghasilkan tiga tipologi kklaster produk hilirisasi karet yaitu : 1. Klaster HVLV cluster berdasarkan volume tinggi dan volume rendah; 2. Klaster EMLM berdasarkan pasar ekspor dan lokal, dan 3. Klaster HMLM berdasarkan mulplier efek tinggi dan rendah. Hubungan antar aktor dalam implementasi kebijakan hilir karet dipetakan berdasarkan peraturan atau kelembagaan dan sistim insentif. Hubungan interaksi antar aktor menunjukkan bahwa petani adalah aktor yang memiliki posisi tawar terendah dan tergantung dengan keberpihakkan aktor lainnya.

\section{DAFTAR PUSTAKA}

Ahmed, M. T, M. Saleh, AF. Abdelkader, A. Abdeelrahim. 2009. El Maghara Scenario A Seatch for Sustainablility and Equity : An Egyptian Case Study.

Balitbangda Provinsi Jambi. 2013. Kajian Pengembangan Industri Hilir di Provinsi Jambi.
Balitbangda Provinsi Jambi. 2017. Klasterisasi Industri Industri Hilir Produk Olahan Berbahan Baku Karet di Provinsi Jambi.

Bappeda Provinsi Jambi. 2013. RTRW Provinsi Jambi tahun 2013-2033.

Badan Pusat Statistik Provinsi Jambi. 2017. Jambi dalam Angka 2017.

Dinas Perindustrian Provinsi Jambi.2017. Buku Data Base Potensi Komoditi Industri Agro Tahun 2017.

Dinas Perkebunan Provinsi Jambi. 2017. Statistik perkebunan 2017.

Dirjen Perkebunan Indonesia. 2016. Statistik Perkebunan Indonesia.

Fauzi, A. 2017. Draf Buku Analisis Keberlanjutan. IPB, Bogor.

Godet, M. 1989. Effective Strategic Management the Prospective Approach. Journal Tecnology Analysis and Strategic Management. Volume 1, Issue 1, 1989, Page 4556.

Godet, M. 2006. Creating Future : Scenario Planning as a Strategic Management tool, London, Economica.

Indonesia Investment.com. Diperoleh tanggal 15 Februari 2018 dari hhtps://www.indonesia.investmen.co $\mathrm{m}$.

Karyudi. 2017. Presentasi Seminar Hilirisasi Karet di Provinsi Jambi. Pusat Penelitian Karet Indonesia, Bogor.

Keputusan Menteri Pertanian Republik Indonesia Nomor : $830 / \mathrm{Kpts} / \mathrm{RC}$. 040/12/2016 tentang penetapan lokasi pengembangan kawasan perkebunan berbasis karet di Provinsi Jambi.

PP Nomor 14 Tahun 2015 tentang Rencana Induk Pembangunan Industri Nasional (RIPIN) 2015-2035.

Peraturan Presiden Nomor 28 tahun 2008 tentang peioritas pengembangan Industri karet dan plastik

Peraturan Menteri Pertanian Nomor 38/Permentan/OT.140/8/2008 tentang Pedoman Pengolahan dan 
Pemasaran Bahan Olahan Karet (BOKAR).

Peraturan Menteri Perdagangan Nomor 53/MDAG/PER/10/2009 tentang Pengawasan Mutu Bahan Olah Komoditi Ekspor Standard Indonesian Rubber yang diperdagangkan.

Peraturan Gubernur Provinsi Jambi No. 15 Tahun 2016 tentang Petunjuk pelaksanaan pengolahan, pemasaran dan pengawasan bokar yang diperdagangkan di Provinsi Jambi.
Porter, M. 1998. Cluster and the new economics of competition, Harvard Business Review,vol.7,no.6, pp. 6-15

Seelig, T. 2017. Innovation \& Entrepreneurship at Stanford. Author, What I Wish I Knew When I Was 20, inGenius, Creativity. Diperoleh tanggal 10 Oktober 2017 dari Rules http://www.tinaseelig.com/

www.kamusdata.com. Daftar 20 Negara Penghasil Karet Alam Terbesar di Dunia. Diperoleh Tanggal 20 September 2017. 